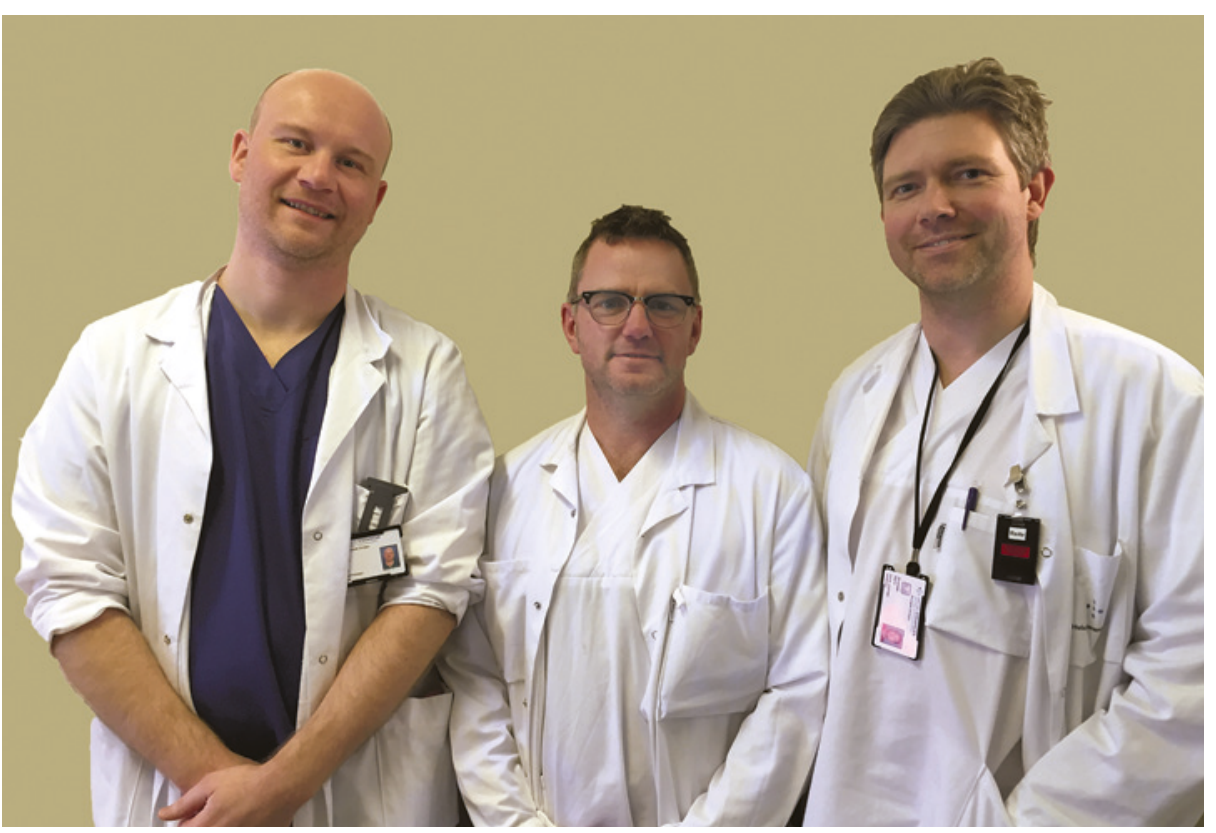

Fra venstre: Kjetil Søreide, Morten Vetrhus og Andreas Reite. Foto: Janne Haugland Karim

\title{
Ruptur av aortaaneurisme i Sør-Rogaland
}

En tredel av dem som ble registrert med rumpert abdominalt aortaaneurisme i Stavanger-området over en 12-årsperiode, overlevde. Av dem som ble operert, overlevde om lag halvparten.

Ruptur av abdominalt aortaaneurisme er en livstruende akutt kirurgisk tilstand, men det finnes få epidemiologiske data om forekomsten. I en studie fra Stavanger universitetssjukehus er forløpet til pasienter med ruptur av abdominalt aortaaneurisme i perioden 2000-12 kartlagt (1).

Studien omfattet 216 pasienter med ruptur av abdominalt aortaaneurisme, hvorav 20 døde før ankomst sykehus. Dette innebærer en justert insidensrate på 11,0 per 100000 innbyggere per år. Insidensen for menn var nesten fire ganger høyere enn for kvinner (17,6 versus 4,7). Justert mortalitet var 7,5 per 100000 innbyggere per år. Av de 196 pasientene som kom til sykehus i live, ble $73 \%$ operert. Av disse døde $51 \%$ under eller kort tid etter operasjonen. 90-dagers mortalitet hos samtlige pasienter var $68 \%$. Det var ingen signifikante forskjeller i insidens eller mortalitet mellom de første og siste årene av studieperioden.

- Denne studien viser en lavere totaldødelighet av rumpert abdominalt aortaaneurisme enn de fleste andre studier og metaanalyser, sier Andreas Reite, som er førsteforfatter av artikkelen, hans første. - Dette kan skyldes at færre pasienter døde prehospitalt og at intervensjonsraten var høyere hos pasienter innlagt i live, sier han.

- En styrke ved studien er at Stavanger universitetssjukehus dekker en definert populasjon der både sykehusdata og obduksjonsdata er tilgjengelig. Svakheter er lav obduksjonsrate og at så få pasienter fikk diagnosen utenfor sykehus, sier Reite.

\section{Kirurgisk forskning i Stavanger}

Forfatterne tilhører et større kirurgisk forskningsmiljø ved Stavanger universitetssjukehus, der akuttkirurgiske tilstander er et av forskningstemaene. Studien er en del av doktorgradsarbeidet til Andreas Reite, som er konstituert overlege ved sykehusets kirurgiske avdeling. Veiledere er overlege Morten Vetrhus og Kjetil Søreide, som er konstituert overlege og professor II ved Universitetet i Bergen. Prosjektet er et samarbeid med Christian Lycke-Ellingsen, overlege ved Avdeling for patologi og ansatt ved Folkehelseinstituttet, og Jan Terje Kvaløy, som er statistiker og professor ved Universitetet i Stavanger.

\section{Lise Mørkved Helsingen \\ Tidsskriftet}

\section{Litteratur}

1. Reite A, Søreide K, Ellingsen CL et al. Epidemiology of ruptured abdominal aortic aneurysms in a well-defined Norwegian population with trends in incidence, intervention rate, and mortality. J Vasc Surg 2015; e-publisert 3.2.2015.
Ordforklaringer

Ruptur avabdominalt aortaaneurisme: Sprukket utvidelse av hovedpulsåren i buken som medfører et stort blodtap og høy risiko for død.

Justerte insidensrater: Beskriver forekomsten av sykdom i en befolkning der forekomsten er justert i forhold til alder og kjønnsfordeling i den aktuelle befolkningen.

Mortalitet (mortalitetsrate): Dødelighet for en sykdom i en definert befolkning over et definert tidsrom.

Intervensjonsrate: Antallet pasienter med en sykdom som fikk behandling (operasjon) sammenliknet med det totale antall pasienter med sykdommen.

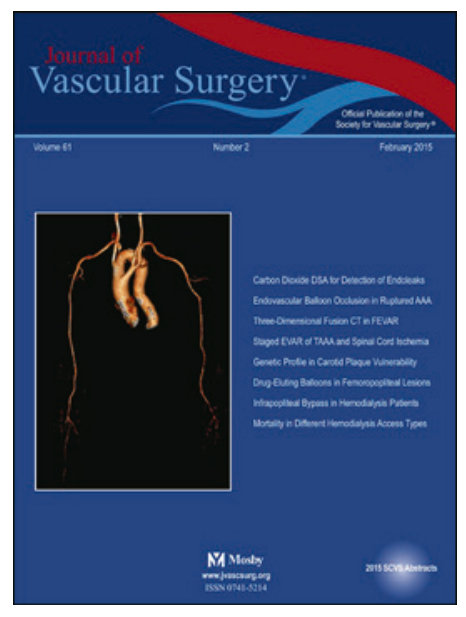

Artikkelen ble e-publisert i Journal of Vascular Surgery 3.2. 2015 